\title{
Haemoglobinopathies
}

\section{The pathophysiology of beta-thalassaemia major}

\author{
C. B. MODELL
}

\section{From the Department of Paediatrics, University College Hospital, London}

The diagnosis of $\beta$-thalassaemia major is by the typical blood film and the presence of more than $20 \%$ of fetal haemoglobin. The defect in $\beta$-thalassaemia is in the switch from $\gamma$ to $\beta$-chain synthesis and it is clear that the failure to switch on the $\beta$ chains is in some way related to a failure to switch off the $\gamma$ chains, perhaps because the same mutated factor is responsible, in opposite senses, for the control of both. One of the most remarkable features of the disease is the heterogeneous distribution of $\mathrm{HbF}$ among the peripheral red cells, which indicates immense variation, from cell to cell, in the degree to which $\mathrm{HbA}$ synthesis is depressed and HbF synthesis permitted. However, unlike the situation in hereditary persistence of fetal haemoglobin, $\gamma$-chain synthesis is always repressed to a substantial extent, so that the total non- $\alpha$ chain, i e, combined $\beta, \delta$, and $\gamma$-chain synthesis is reduced to one quarter or less of normal (Weatherall and Clegg, 1972). Alpha-chain synthesis appears to proceed normally, so that unpaired $\alpha$ chains accumulate rapidly in the thalassaemic cells. These are unstable (Huehns and Shooter, 1966) and precipitate to form inclusion bodies (fig 1); they may also interfere with the functioning of the nuclear and the cell membranes.

The fundamental lesion in $\beta$-thalassaemics may then be described as a defect in $\beta$-chain production with consequent precipitation of unpaired $\alpha$ chains. Figure 2, on the other hand, shows two brothers from Qatar with thalassaemia major. Both brothers are severely stunted, have typical facial and skull changes, gross hepatosplenomegaly and stick-like arms and legs. Both pass dark urine. In common with other thalassaemic patients they show a degree of disability which seems out of proportion to the degree of the anaemia when compared with, e $\mathrm{g}$, iron deficiency or $\mathrm{HbS}$ disease. The question that should be asked is, how does a mutation affecting the control of $\mathrm{Hb} \beta$-chain synthesis produce these final consequences for the patients?

The current idea is that most of the gross pathology can be related not only to a deficiency of adult haemoglobin, but also to the existence of precipitates of unpaired $\alpha$ chains in the developing red

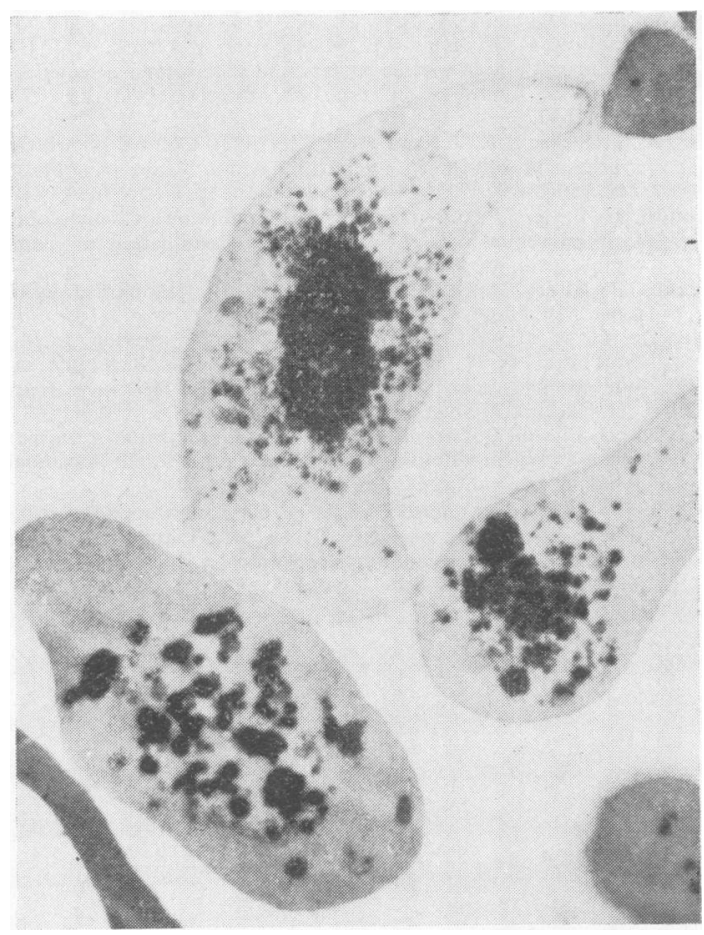

Fig 1 Electron micrograph taken by Dr Siro Koyama of red cells in the peripheral blood in thalassaemia major. Alpha-chain precipitates dominate the picture.

cells. These appear to be responsible for premature cell death in the bone marrow and hence for ineffective erythropoiesis and dark urine; and also for the abnormal red cells in the peripheral blood that are the cause of hypersplenism. The pathology of $\beta$-thalassaemia major is summarized in figure 3 .

Though this paper is not to be concerned with treatment it should be mentioned here that there have been considerable recent advances in management. Modern treatment is directed first towards correcting the anaemia by maintaining the haemoglobin within the normal range, as this suppresses the hyperactivity of the bone marrow and eliminates most 


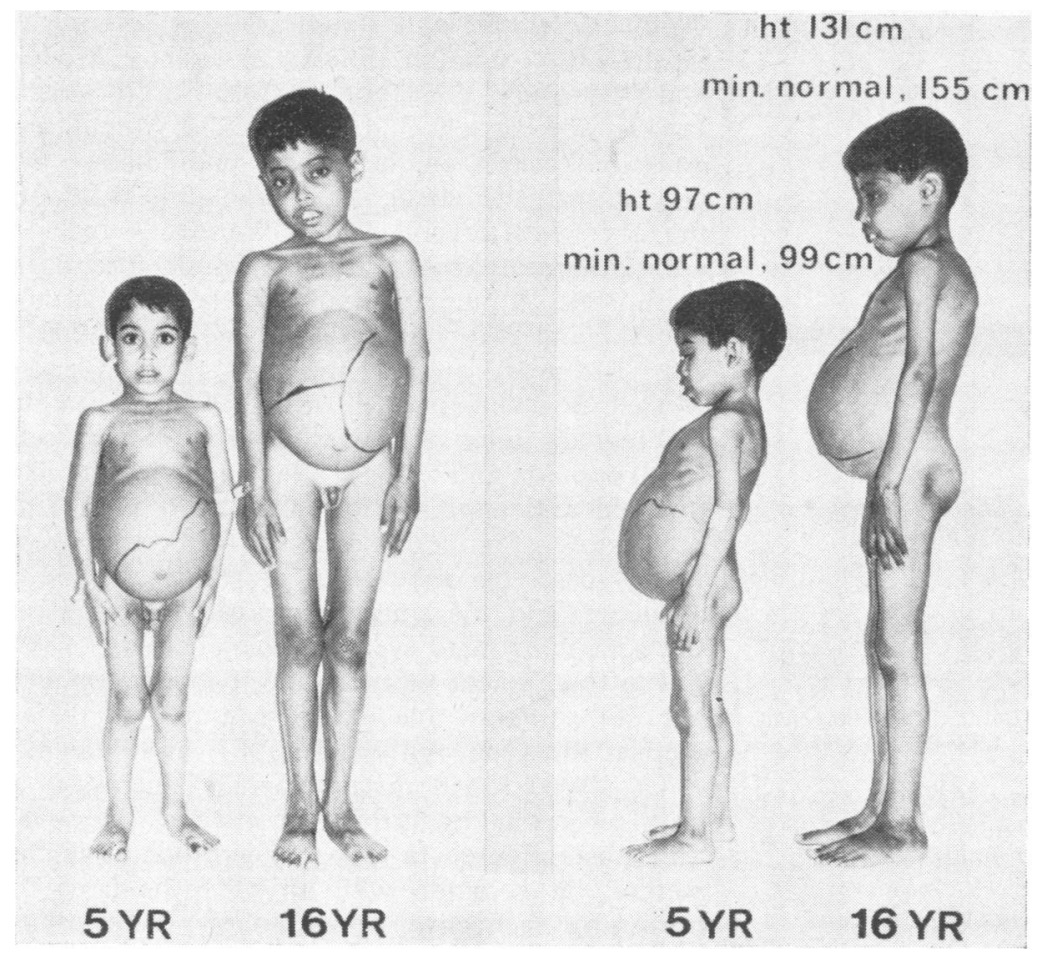

Fig 2 Side and front views of two brothers from Qatar with minimally treated thalassaemia major. Their growth is severely stunted, there is gross hepatosplenomegaly, and the arms and legs are like sticks. Photograph kindly provided by Dr Hugh Jolly.

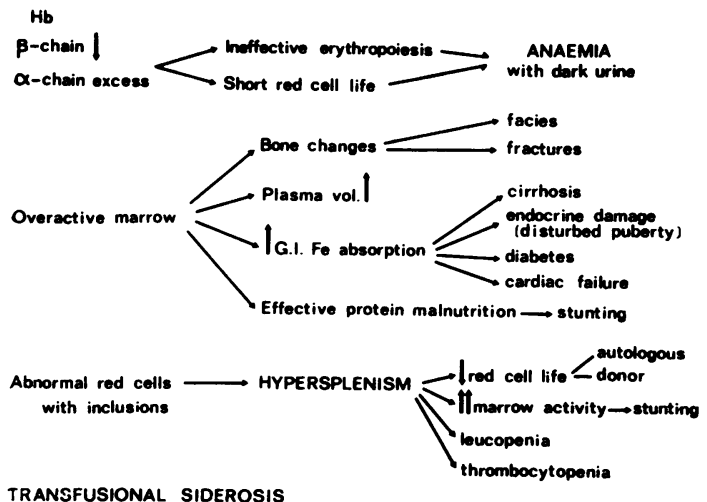

Fig 3 Outline of the pathophysiology of thalassaemia major.

of the pathology that springs from it; secondly, towards removing the spleen when it can be shown to be increasing the transfusion requirement, and this is very common; and thirdly towards controlling transfusional siderosis by the intensive use of iron-chelating agents. Evidence that this treatment is effective is gradually accumulating (Con- stantoulakis, Economidou, Karagiorga, Katsantoni, and Gyftaki, 1974; Modell and Beck, 1974; O'Brien, 1974), and there is every reason to hope that the prognosis in thalassaemia, both in the short and the long term, is improving steadily. To return to the pathology, I would like to trace in some detail the consequences of the ineffective erythropoiesis, and to follow this with a shorter discussion of hypersplenism.

\section{Ineffective Erythropoiesis}

Ineffective erythropoiesis is the outstanding feature of thalassaemia major, and is unparalleled in any other condition. The bone marrow expands to occupy all the space available, yet the reticulocyte count is rarely much above normal. In the bone marrow the myeloid : erythroid ratio is reversed, and dynamic studies show an arrest of maturation in the early polychromatic erythroblasts. Figure 4 , based on the work of Wickramsinghe, McElwain, Cooper, and Hardisty (1970), shows the numbers of basophilic and early polychromatic erythroblasts in the different stages of the cell cycle compared with the normal. There is substantial failure of the thalas- 


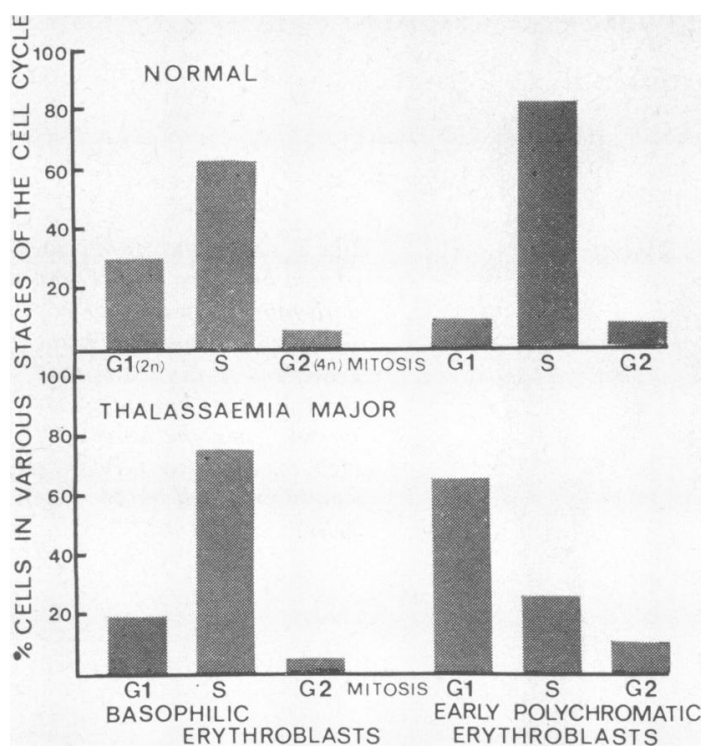

Fig 4 The percentage of basophil erythroblasts and early polychromatic erythroblasts in different stages of the cell cycle, in normal (above) and thalassaemic (below) bone marrow. Two complete cell cycles are represented. $G_{1}$ is the growth phase following mitosis when the cells are still diploid, $S$ is the phase of DNA synthesis leading up to the next cell division, and $G_{2}$ is the growth phase preceding division. Then mitosis occurs and the whole cycle is repeated. There is a striking arrest, in thalassaemic bone marrow, at the $G_{1}$ phase among early polychromatic erythroblasts.

(Based on the work of Wickramsinghe and associates, 1970.)

saemic polychromatic erythroblasts to begin the cycle of DNA synthesis that should lead up to the final mitosis of the erythroid pathway. This arrest occurs at a stage when $\mathrm{Hb}$ synthesis has really only just begun (Thorell, 1948), yet the evidence is that the intracellular accumulations of $\alpha$ chains already occur at this stage (Yataganas and Fessas, 1969), and though they are not conspicuously attached to the cell membrane, they may be associated with the nuclear membrane, indent it, and also appear as intranuclear inclusions(Polliack,Yataganas, and Rachmilewitz, 1974). Thus there is good morphological evidence of early intracellular and particularly, nuclear, damage by abnormal protein precipitates.

The arrested cells may die, mature more slowly, or pass into the peripheral blood as they are. The cells that do emerge into the circulation are strongly heterogeneous in size, shape, and content of $\mathrm{HbF}$ and $\mathrm{HbA}$. They are defective in several ways, eg, the membrane is visibly abnormal (Hoffman,
Wolman, Hillier, and Parpart, 1956), excessively sensitive to oxidation (Stocks, Offerman, Modell, and Dormandy, 1972), and leaky to $\mathrm{Na}^{+}$(Cividalli, Locker, and Russell, 1971). ${ }^{51} \mathrm{Cr}$ studies with autologous cells show at least two populations, one very short lived (Bailey and Prankerd, 1958) but the others with a relatively long life span $\left({ }^{51} \mathrm{Cr} \mathrm{T}_{\frac{1}{}}=\right.$ 6.5-25d: mean about 17 days) (Smith, Erlandson, Stern, and Schulman, 1960; Malamos, Belcher, Gyftaki, and Binopoulos, 1961 ; Nightingale, Prankerd, Richards, and Thompson, 1972; Blendis, Modell, Bowdler, and Williams, 1974). This and the differentially long survival of $\mathrm{HbF}$-containing cells (Loukopoulos and Fessas, 1965) support the idea that red cells appear in the circulation as a result of a process of natural selection in the bone marrow. In any case, the production of red cells is never adequate, and the consequent anaemia stimulates the bone marrow to ever-increasing activity.

The total extent of the ineffective erythropoiesis has not yet been adequately measured in thalassaemia. Sturgeon and Finch (1957) and Malamos et al (1961) found marrow activity increased to six times normal by ferrokinetic methods. However, this must represent a gross underestimate as this method, in common with all other methods for measuring ineffective erythropoiesis, depends on haemoglobin turnover, whereas in thalassaemia there is defective $\mathrm{Hb}$ synthesis, and indeed most of the cell damage and death appear to occur before the cells are well haemoglobinized, ie, erythropoiesis must be at least $90 \%$ ineffective in severe thalassaemia major.

Clinically, the 24-hour urinary uric acid should reflect marrow cell death, as the uric acid is derived almost entirely from DNA and RNA breakdown. Figure 5 shows that, though the plasma uric acid is usually in the normal range, the 24-hour urinary uric acid calculated on a weight basis is many times above the adult normal. High transfusion, which reduces bone marrow activity, reduces the urinary uric acid towards, but not into, the normal range. It is not surprising that of the patients shown, one has had a uric acid stone, and one has big kidneys with a concentration defect.

The urine also contains dark pigments which, like the uric acid, reflect the degree of ineffective erythropoiesis because they are a direct result of $\alpha$-chain precipitation. They are not bilirubin or porphyrins, but abnormal haem breakdown products, conjugated dipyrryl methenes (KreimerBirnbaum, Pinkerton, Bannerman, and Hutchinson, 1966). These are also found in the urine of patients with Heinz-body anaemia, and are probably produced in both conditions by intralysosomal digestion in reticuloendothelial cells of the haemo- 


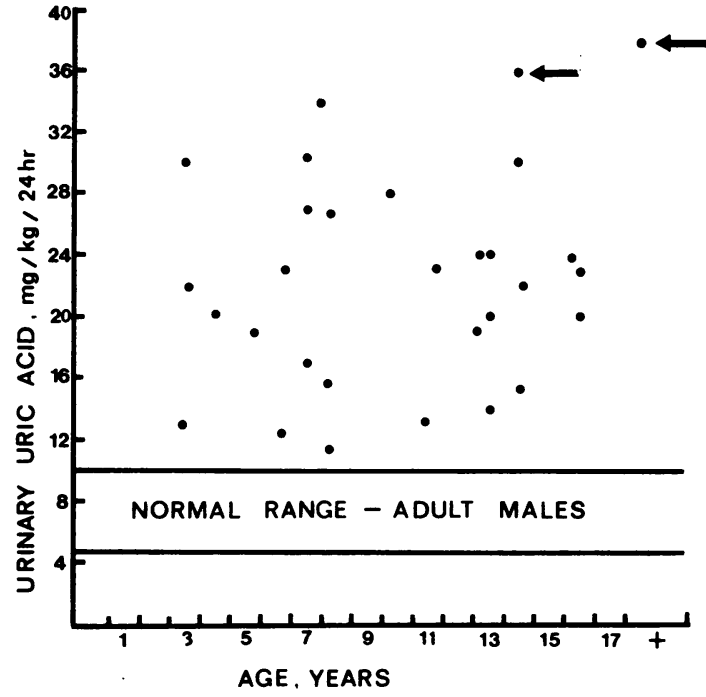

Fig 5 Twenty-four-hour urinary uric acid excretion in patients with thalassaemia major. One of the patients marked with arrows has had a uric acid stone, and the other has big kidneys with a concentration defect. globin precipitates. They are of clinical value, as a clinical diagnosis of thalassaemia major can be made when they are present in a child of suitable parentage with anaemia and hepatosplenomegaly.

The gross bone marrow expansion consequent on severe ineffective erythropoiesis has secondary effects on the bones and the plasma volume, on growth, and on gastrointestinal iron absorption which may lead to the full-blown picture of haemochromatosis. These effects will be examined in turn.

Figure 6 illustrates the typical bony lesions, and it is worth noticing the nutrient foramina in the phalanges (marked with arrows). These are not normally visible, and suggest the large proportion of the circulation that must be diverted through the grossly expanded marrow. This probably accounts for the plasma volume expansion that has long been known in thalassaemia major (Erlandson, Schulman, and Smith, 1960), but has been attributed to splenic enlargement, as plasma volume expansion is common in association with splenomegaly. However, direct measurements in untransfused thalassaemic patients before and after splenectomy (Blendis et al, 1974) show little change in the ex-
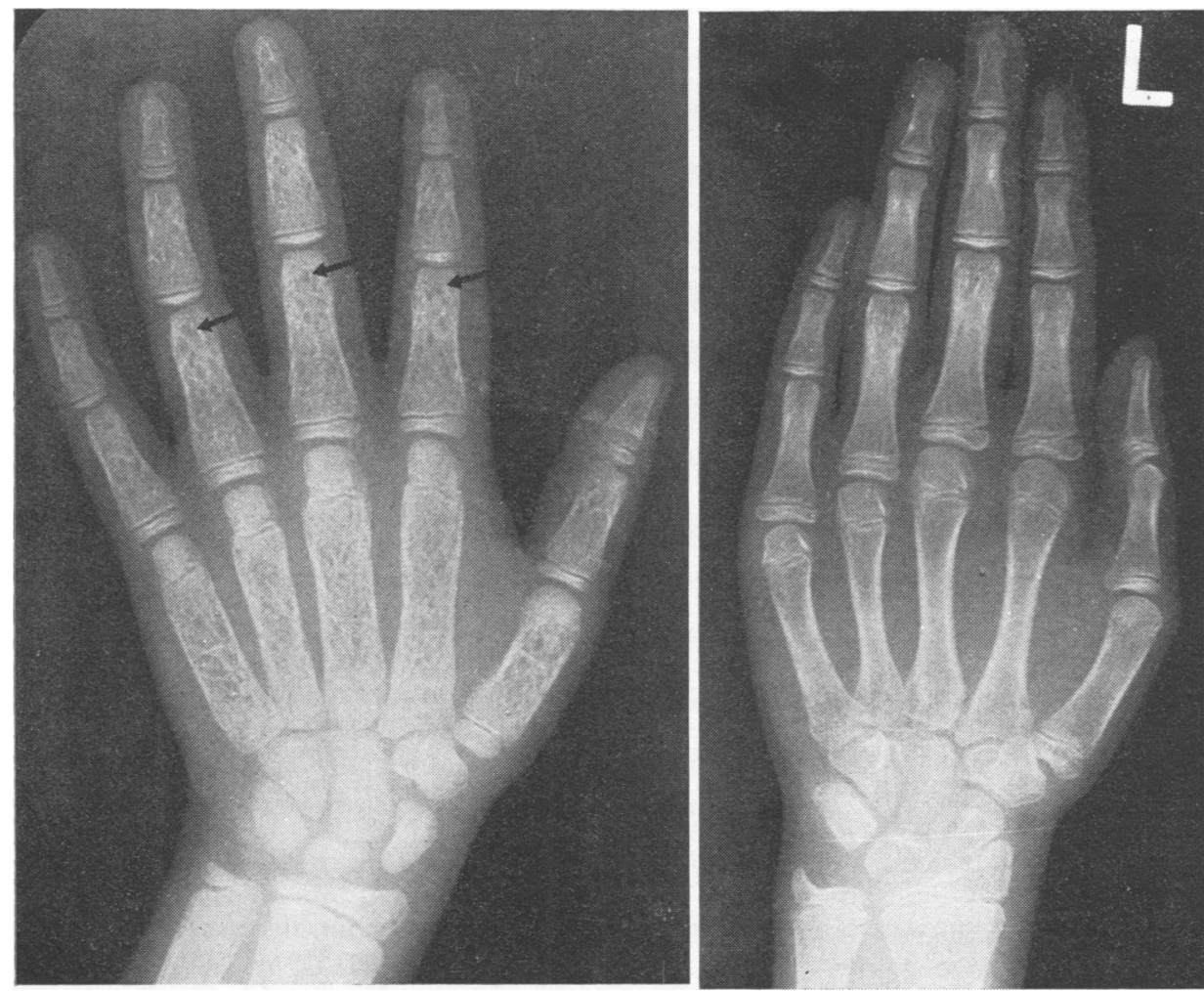

Fig 6 The typical bone changes of thalassaemia. On the left is a radiograph of the hand of a 12-yearold untransfused thalassaemic patient compared with $a$ normal 12-year-old hand on the right. Note the nutrient foramina (arrowed) visible in the first phalanges. 


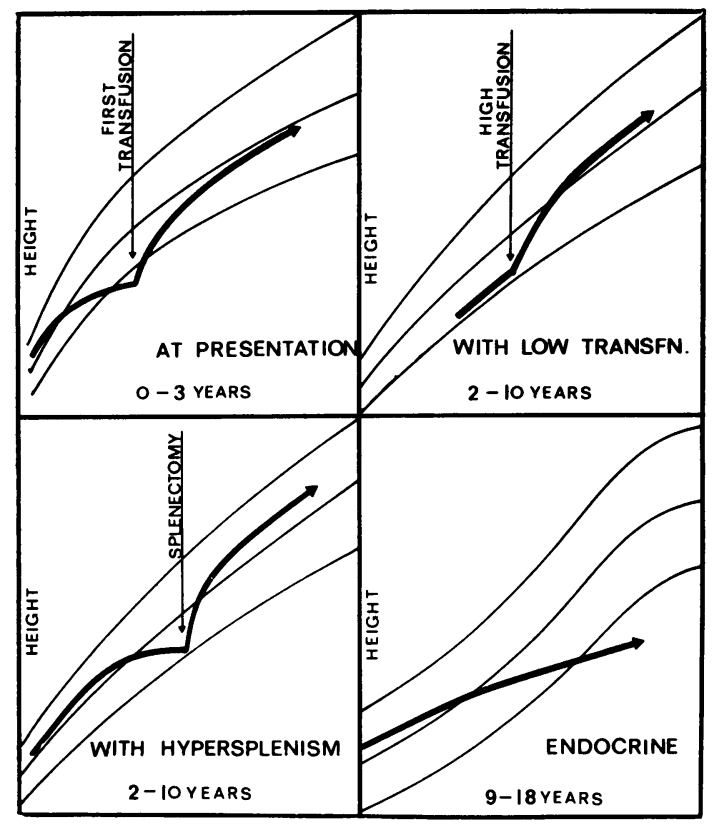

Fig 7 Growth failure in thalassaemia major. Each growth curve is based on an actual growth curve. Growth failure at presentation (top $L$ ) is related to progressive bone marrow expansion. In early childhood it is related to excessive marrow expansion, either due to a transfusion scheme that is too low (top $R$ ), or in an effort to compensate for hypersplenism (bottom L). Growth failure at puberty (bottom $R$ ) has an endocrine basis and does not respond to changes in the transfusion scheme.

panded plasma volume, which remains about $1 \cdot 7$ times normal, so this must be attributable to something else: it is probably the result of blood volume expansion in response to the shunting of a large fraction of the cardiac output through the bone marrow. Since further expansion of the red cell mass is not possible, the blood volume expansion occurs in the plasma compartment alone. This expansion is reduced to normal by high transfusion which suppresses the bone marrow (Modell, in preparation).

The effect of ineffective erythropoiesis on growth is generally seen in early childhood, and is quite different from the endocrine growth failure that occurs in older, iron-loaded patients. Both types are represented in figure 7. Early failure of growth occurs only in association with a grossly overactive marrow, eg, at presentation, or when the transfusion scheme is too low, or when there is compensating bone marrow expansion in the presence of hypersplenism. It can always be corrected by raising the transfusion scheme or by splenectomy, as appropriate. Clinically, such stunting is associated with anorexia, which resembles the anorexia of patients with malignancies, in which there is also considerable cell death. This suggests that stunting is due to the release of some appetite suppressant by cells dying in the bone marrow, rather than to the sequestration by the thalassaemic cells of some factor necessary for growth. The stunting does not respond to folic acid therapy.

Clinically, the most striking aspect of the disturbance in growth is the lack of muscular tissue, which gives the limbs their characteristic stick-like appearance, and causes the patient to complain of limited exercise tolerance due to weakness rather than to shortness of breath. It is reflected in the 24-hr urinary creatinine. Since $2 \%$ of muscle creatine is broken down to creatinine per day, and this is the only source of urinary creatinine, the 24-hr urinary creatinine is constant and is a rough estimate of muscle mass. Figure 8 shows that low-transfused

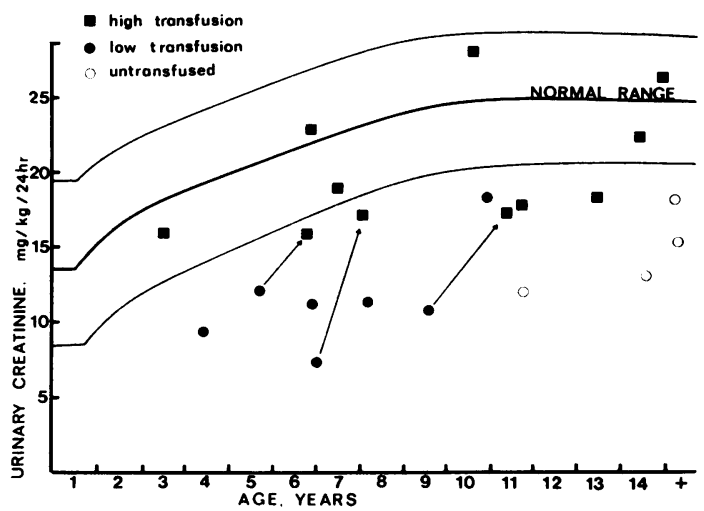

Fig 8 Urinary creatinine excretion in thalassaemia major, expressed as $\mathrm{mg} / \mathrm{kg} / 24 \mathrm{hr}$. The normal curve is taken. from Stearns et al, 1958: Untransfused patients $(\bigcirc)$ and those on a low transfusion scheme (O) have a lower creatinine excretion than those on a high transfusion scheme ( $\square$ ). The three sets of points connected by arrows show the effect of shifting patients from a low to a high transfusion scheme.

or untransfused patients have a much lower creatinine excretion than high-transfused patients, whose muscle mass appears to be in the normal range, in accordance with their normal physical appearance and exercise tolerance.

Finally, the gross bone-marrow overactivity leads to excessive gastrointestinal iron absorption: of the various factors controlling this, bone marrow activity is the most influential (Erlandson, Walden, 
Stern, Hilgartner, Wehman, and Smith, 1962) probably because the marrow cells selectively remove iron from the avid end of transferrin (Fletcher and Huehns, 1967). Absorption can reach $80 \%$ of dietary intake (Erlandson et al, 1962), and in small children the rate of iron loading from absorption may rival the rate of iron loading from transfusion. The table,

\begin{tabular}{lcl}
\hline & $\begin{array}{l}\text { Mean } \\
\text { Haemoglobin } \\
(\mathrm{g} / \mathrm{dl})\end{array}$ & $\begin{array}{l}\text { Mean Iron } \\
\text { Absorption } \\
(\% \text { of oral dose })\end{array}$ \\
\hline $\begin{array}{l}\text { Normal child } \\
\text { Thalassaemia major } \\
\begin{array}{l}\text { Before transfusion } \\
\text { After transfusion }\end{array}\end{array}$ & $12 \cdot 6-14$ & $3-27$ \\
\hline
\end{tabular}

Table Oral iron absorption ( $5 \mathrm{mg} \mathrm{FeSO}_{4}$ taken fasting) in 16 patients with thalassaemia major before and after transfusion $^{1}$

${ }^{1}$ From Erlandson et al (1962)

based on the work of Erlandson and her associates (1962), shows that transfusion suppresses the increased iron absorption, and this is one of the compensations of a high transfusion scheme. Even in the absence of transfusion, thalassaemia major is an iron-loading disease, but patients on maintenance transfusion become iron loaded faster, and it is this group that we have been able to study by means of liver biopsies and endocrine studies. Though in them haemochromatosis is the result of treatment, this is a convenient point to discuss it. It is now clear that unless the iron overload is treated by long-term chelation therapy, these patients develop frank cirrhosis by 12 to 16 years of age. Though no pituitary abnormality has been demonstrated, they commonly develop relative adrenal insufficiency from as early as 8 years of age (McIntosh, 1974), and this may contribute to the sudden death that seems characteristic of the disease. Diabetes occurs sporadically, possibly only in patients with a family history of the disease, and hypoparathyroidism is common in heavily iron-loaded patients. The typical growth failure starting around the time of puberty, and the delayed puberty itself, have not been adequately explained. Death from iron overload is usually due to cardiac failure and may be sudden. It is to be hoped that long-term therapy with the iron-chelating agent desferrioxamine will prevent the development of this distressing pathology.

\section{Hyperplasia of the Reticuloendothelial System}

The remaining striking aspect of thalassaemia is the reticlioendothelial hyperplasia represented by hepatosplenomegaly. Splenic enlargement is not

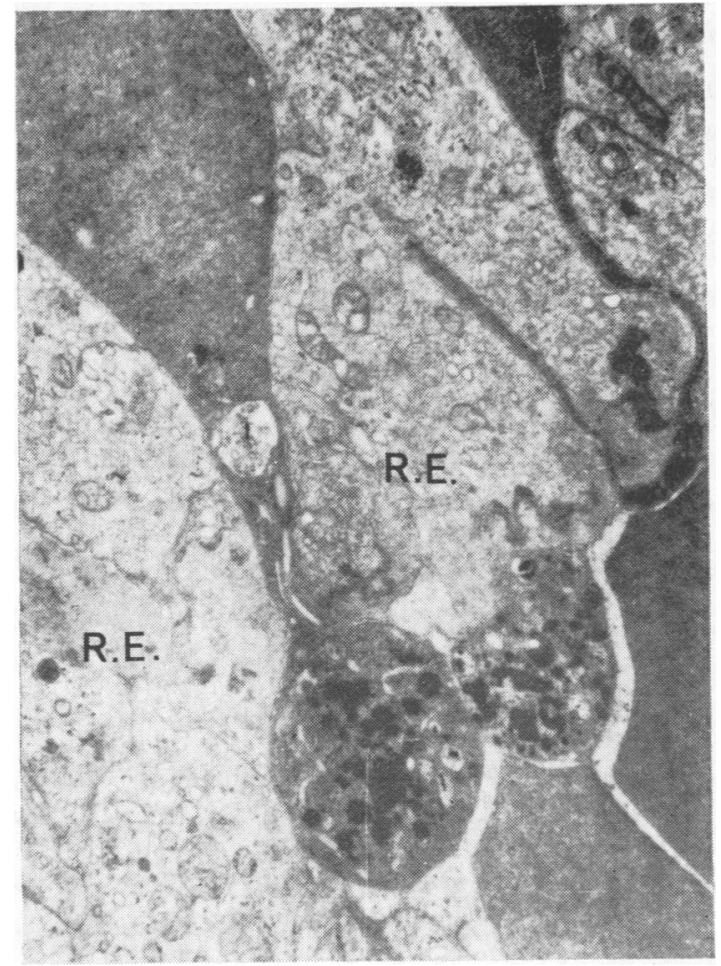

Fig 9 Electron micrograph taken by Dr Siro Koyama, of cells in the red pulp of the spleen from a thalassaemic patient. $A$ red cell containing inclusions is passing between two reticuloendothelial cells $(R$.E.) from the splenic cord (bottom R) towards the splenic sinus (top L). The inclusions have been stroked down into the tail of the red cell, which will be removed by the reticuloendothelial cells. The rest of the red cell will return, 'pitted', to the circulation.

primarily due to extramedullary erythropoiesis: it happens because the spleen is presented with abnormal red cells. The red cells are expected to traverse the walls of the splenic sinuses between the reticuloendothelial cells, which stroke down the passing erythrocytes so that any inclusions ( $\alpha$ chains, nuclei, Howell-Jolly bodies) are squeezed into their tails. Then the reticuloendothelial cells selectively ingest this part of the red cell and the remainder pass back into the circulation (Koyama, Aoki, and Deguchi, 1964; Slater, Muir, and Weed, 1968). This process is illustrated in figure 9, an electron micrograph taken by Dr Koyama of material from the spleen of one of our patients. This process necessarily involves some delay and the spleen becomes engorged, enlarges, and finally in most cases causes some accelerated destruction of autologous or donor red cells or both. It then becomes appro- 
priate to remove the spleen. Before splenectomy the peripheral blood film shows relatively few nucleated red cells but after splenectomy nucleated cells, which would normally be 'pitted', appear in the circulation in large numbers. From the fact that these persist indefinitely, it is clear that the pitting function is never taken over by any other organ.

Hypersplenism sometimes causes further gross plasma volume expansion, and can lead to death from thrombocytopenia. In patients on a low transfusion scheme it may exacerbate the disease to the point where they die in heart failure; and in patients on a high transfusion scheme, by increasing the blood requirement, it may accelerate iron overload. For these reasons opinion is now swinging in favour of splenectomy in thalassaemia when indicated after a long period of being against it.

\section{Conclusion}

In conclusion, in $\beta$-thalassaemia major the cellular event which produces much of the pathology is precipitation of unpaired haemoglobin $\alpha$ chains. This causes ineffective erythropoiesis, bone-marrow expansion, and hypersplenism from which the gross physical pathology follows. In a fundamental approach to treatment it would be reasonable to attempt to reduce $\alpha$-chain synthesis as well as to seek to stimulate $\beta$ - or $\gamma$-chain synthesis.

I am grateful to Professors L. B. Strang and E. R. Huehns for help and advice, to Dr S. Koyama for the electron micrographs, to Dr Hugh Jolly for the photograph of two patients with severe thalassaemia major, and to the Sir Halley Stewart Trust for a research grant.

\section{References}

Bailey, I. S., and Prankerd, T. A. J. (1958). Studies in thalassaemia. Brit. J. Haemat., 4, 150-155.

Blendis, L., Modell, C. B., Bowdler, A. J, and Williams, R. (1974). Some effects of splenectomy in thalassaemia major. Brit. $J$. Haemat., in press.

Cividalli, G., Locker, H., and Russell, A. (1971). Increased permeability of erythrocyte membrane in thalassemia. Blood, 37, 716724.

Constantoulakis, M., Economidou, J., Karagiorga, M., Katsantoni A., and Gyftaki, E. (1974). Combined long-term treatment of hemosiderosis with desferrioxamine and DTPA in homozygous $\beta$-thalassemia. Ann. N. Y. Acad. Sci., 232, 193-200.

Erlandson, M. E., Schulman, I., and Smith, C. H. (1960). Studies on congenital hemolytic syndromes. III. Rates of destruction and production of erythrocytes in sickle cell anemia. Pediatrics, 25, 629-644.

Erlandson, M. E., Walden, B., Stern, G., Hilgartner, M. W., Wehman, J., and Smith, C. H. (1962). Studies on congenital hemolytic syndromes. IV. Gastrointestinal absorption of iron. Blood, 19, 359-378.

Fletcher, J., and Huehns, E. R. (1967). The uptake of plasma iron by immature red cells. J. Physiol. (Lond.), 192, 38-39P.

Hoffman, J. F., Wolman, I. J., Hillier, J., and Parpart, A. K. (1956). Ultrastructure of erythrocyte membranes in thalassemia major and minor. Blood, 11, 946-956.

Huehns, E. R., and Shooter, E. M. (1966). Further studies on the isolation and properties of $\alpha$-chain sub-units of haemoglobin. Biochem. J., 101, 843-851.

Koyama, S., Aoki, S., and Deguchi, K. (1964). Electron microscopic observations of the splenic red pulp with special reference to the pitting function. Mie. med., J. 14, 143-188.

Kreimer-Birnbaum, M., Pinkerton, P. H., Bannerman, R. M., and Hutchison, H. E., (1966). Dipyrrolic urinary pigments in congenital Heinz-body anaemia due to $\mathrm{Hb}$ Köln, and in thalassaemia. Brit. med.J., 2, 396.

Loukopoulos, D., and Fessas, P. (1965). The distribution of hemoglobin types in thalassemic erythrocytes. J., clin. Invest., 44, 231240.

McIntosh, N., (1974). Endocrinopathy in Thalassaemia Major, in press.

Malamos, B., Belcher, E. H., Gyftaki, E., and Binopoulos, D. (1961). Simultaneous radioactive tracer studies of erythropoiesis and red-cell destruction in thalassaemia. Brit. J. Haemat., 7, $411-429$.

Modell, C. B., and Beck, J. (1974). Long-term desferrioxamine in thalassemia. Ann. N.Y. Acad. Sci., 232, 201-210.

Nightingale, D., Prankerd, T. A. J., Richards, J. D. M., and Thompson, D. (1972). Splenectomy in anaemia. Quart. J. Med., 41, 261-267.

O'Brien, R. T. (1974). Ascorbic acid enhancement of desferrioxamineinduced urinary iron excretion in thalassemia major. Ann. N.Y. Acad. Sci. , 232, 221-225

Polliack, A., Yataganas, X., and Rachmilewitz, E. A. (1974). Ultrastructure of the inclusion bodies and nuclear abnormalities in B-thalassemic erythroblasts. Ann. N.Y. Acad. Sci, 232, 261-282.

Slater, L. M., Muir, W. A., and Weed. R. I. (1968). Influence of splenectomy on insoluble hemoglobin inclusion bodies in $\beta$ thalassemic erythrocytes. Blood, 31, 766-777.

Smith, C. H., Erlandson, M. E., Stern, G., and Schulman, I. (1960) The role of splenectomy in the management of thalassemia. Blood, 15, 197-211.

Stearns, G., Newman, K. J., McKinley, J. B., and Jeans, P. C. (1958), The protein requirements of children from 1-10 years of age. Ann. N.Y. Acad. Sci., 69, 857-868.

Stocks, J., Offerman, E. L., Modell, C. B., and Dormandy, T. L. (1972). The susceptibility to autoxidation of human red cell lipids in health and disease. Brit. J. Haemat., 23, 713-724.

Sturgeon, P., and Finch, C. A. (1957). Erythrokinetics in Cooley's anemia. Blood, 12, 64-73.

Thorell, B. (1948). The relation of the synthesis of hemoglobin to the cellular growth during normal and certain pathological conditions. Acta. path. microb. scand, 25, 54-65.

Weatherall, D. J., and Clegg, J. B. (1969). Disordered globin synthesis in thalassemia. Ann, N.Y. Acad. Sci., 165, 242-252.,

Weatherall, D. J., and Clegg, J. B. (1972). The Thalassaemia Syndromes, 2nd ed. Blackwell, Oxford.

Wickramasinghe, S. N., McElwain, T. J., Cooper, E. H., and Hardisty, R. M. (1970). Proliferation of erythroblasts in beta-thalassaemia. Brit. J. Haemat., 19, 719-727.

Yataganas, X., and Fessas, P. (1969). The pattern of hemoglobin precipitation in thalassaemia and its significance. Ann. N.Y, Acad. Sci., 165, 270-287. 